\title{
MOTIVASI BELAJAR DAN KOMPETENSI PEDAGOGIK SERTA PENGARUHNYA TERHADAP HASIL PEMBELAJARAN PADA PROGRAM KEAHLIAN AKUNTANSI
}

\author{
Dudung Ma'ruf Nuris \\ Universitas Negeri Malang \\ e-mail: dudung.ma'ruf.fe@um.ac.id
}

\begin{abstract}
Abstrak
Kompetensi pedagogik sebagai kompetensi yang harus dikuasai guru di samping kompetensi profesional, sosial, dan kepribadian. Penelitian ini bertujuan untuk mencari dampak motivasi belajar dan kompetensi pedagogik terhadap hasil pembelajaran di bidang akuntansi keuangan. Riset dilakukan terhadap 36 siswa Sekolah Menengah Kejuruan dan jenis penelitian adalah penelitian eksplanasi. Sumber yang dipakai berupa data yang sudah tersedia yaitu nilai akhir semester dan penyebaran instrumen. Teknik dokumentasi dan teknik kuisioner dipakai dalam mengumpulkan data di penelitian ini. Analisis deskriptif dan analisis inferensial dipilih untuk mengidentifikasi hasil akhir riset. Hasil penelitian menunjukkan bahwa terdapat pengaruh motivasi belajar siswa dan kompetensi pedagogik terhadap hasil pembelajaran akuntansi keuangan. Hal ini ditunjukkan oleh persamaan dari hasil analisis regresi sehingga didapatkan nilai konstan 98,850 disamping itu nilai motivasi belajar ditemukan sejumlah 0,345 dan nilai kompetensi pedagogik guru teridentifikasi 0,377. Berdasarkan hasil penelitian dapat disimpulkan bahwa motivasi belajar dari siswa mempunyai pengaruh terhadap hasil pembelajaran akuntansi dan kompetensi pedagogik yang dimiliki dapat mempengaruhi hasil pembelajaran akuntansi keuangan. Hasil penelitian juga membuktikan keberlakuan teori behavioristik yang menyebutkan tingkah laku sangat perlu diaplikasikan agar dorongan belajar dan kemampuan guru dapat teruji baik di kelas maupun diluar kelas.
\end{abstract}

Kata Kunci : Motivasi Belajar, Kompetensi Pedagogik, Hasil Pembelajaran

\section{LEARNING MOTIVATION AND PEDAGOGIC COMPETENCE IN THE EFFECT ON ACCOUNTING LEARNING ACHIEVEMENT ON ACCOUNTING PROGRAMME}

\begin{abstract}
Pedagogic competence as a competency that must be mastered by the teacher in addition to professional, social, and personality competencies. This study aims to look at the impact of learning motivation and pedagogical competence on learning outcomes in the field of financial accounting. Research was conducted on 36 Vocational High School students and the type of research was explanatory research. Sources used are in the form of available data, namely the value of the end of the semester and the spread of the instrument. Documentation techniques and questionnaire techniques were used in collecting data in this study. Descriptive analysis and inferential analysis were chosen to identify the results of this study. The results of the study show that there is an influence of student learning motivation and pedagogical competence on the learning outcomes of financial accounting. That is indicated by the equation of multiple regression obtained from a constant value of 98.850 while the value of the learning motivation variable is 0.345 and the value of the teacher's pedagogical competency variable is 0.377 . Based on the results of the study, it can be concluded that the learning motivation of students has an influence on the results of accounting
\end{abstract}


learning and the pedagogical competence that is owned can affect the results of learning of accounting for financial. The results of the study also prove the validity of the behavioristic theory which states that behavior changes as a result of experience both in class and outside the classroom.

Keywords: Pedagogical Competence, Learning Motivation, Learning Achievement

\section{PENDAHULUAN}

Pendidik di semua jenjang pendidikan merupakan subyek yang memegang peranan penting dalam kegiatan pembelajaran dengan maksud membentuk kualitas pendidikan yang baik. Nursyaidah (2015) mengungkapkan bahwa untuk mendapatkan kemampuan faktual, konseptual, prosedural yang diterjemahkan dalam kemampuan kognitif, afektif dan psikomotorik, peran guru sangat diperlukan oleh siswa. Tugas, pokok, dan fungsi seorang pendidik yang utama yaitu mampu menyelenggarakan kegiatan proses belajar mengajar di kelas dan memposisikan pembelajaran sebagai alat untuk mencapai tujuan pendidikan. Di dalam undang-undang yang mengatur perihal dosen dan guru menyebutkan bahwa tugas berupa mengajar di kelas, mendidik perilaku dan sikap siswa, membimbing dalam proses belajar, sampai pada tahap evaluasi merupakan tugas utama yang harus dijalankan di semua jenjang pendidikan baik dasar sampai dengan menengah bahkan pendidikan tinggi, menjadi tugas utama pendidik yang profesional. Pendidik yang berhasil yaitu pendidik yang mampu menghantarkan ketercapaian tujuan nasional khususnya dibidang pendidikan.

Kompetensi yang dimiliki oleh guru dapat mencerminkan bahwa yang bersangkutan mempunyai kualitas yang dipersyaratkan oleh Undang-Undang dalam hal ini tentang profesionalitas dan kepakaran seseorang dalam pendidikan. Umami dan Roesminingsih (2014) menekankan begitu pentingnya penguasaan kompetensi khususnya pedagogik dan perlu dipahami, dan penting sesegera mungkin diaplikasikan di kelas. Oleh karena itu kompetensi ini wajib dipahami dan diterapkan oleh para guru. Wulandari (2013) mengutarakan bahwa keahlian dalam pengelolaan kegiatan belajar di kelas merupakan dalah satu contoh pemahaman akan kompetensi bagian pedagogik. Motivasi belajar juga berperan aktif terlibat dalam proses pembelajaran selain kompetensi pedagogik. Motivasi merupakan keinginan atau kemauan yang muncul baik direncanakan atau tidak direncanakan yang menyebabkan adanya tingkah laku untuk mewujudkan misi tertentu. Putri dan Isnani (2015) menekankan bahwa kegiatan utama dalam bidang pendidikan yaitu terletak pada proses belajar mengajarnya serta sehingga diharapkan dapat mencapai keberhasilan yang ditandai dengan hasil pembelajaran paling maksimal. Beberapa faktor yang telah diketahui sangat berkontribusi dalam kesuksesan siswa mempuh belajar yaitu minat yang timbul dari pribadi pebelajar untuk belajar dan motivasi untuk meningkatkan kadar belajarnya. Hamdu dan Agustina (2011) menyatakan motivasi belajar dan hasil pembelajaran sangatlah berkaitan erat. Adanya dukungan motivasi kuat dari siswa yang muncul tersebut maka diharapkan mereka belajar dengan rajin dan bersungguh-sungguh, dalam aktivitas yang dilakukan di dalam kelas. Dengan demikian, untuk mendukung upaya pembelajaran di sekolah maka motivasi belajar perlu ditanamkan.

Tingkat kompetensi guru yang tergolong belum maksimal akan sangat memprihatinkan semua pihak, hal ini dikarenakan profesi guru sebagai profesi yang keberadaannya sudah lama diharapkan oleh masyarakat untuk selalu dituntut memiliki citra yang baik untuk kemajuan bangsa di masa depan. Guru merupakan penentu masa depan sebuah bangsa dan komponen yang paling penting dalam sistem pendidikan serta menjadi jantung dan simbol pendidikan itu 
sendiri. Permasalahan pendidikan secara nasional sangat kompleks dan memerlukan penanganan yang intensif. Kompleksitas permasalahan yang dihadapi guru menyebabkan guru dianggap sebagai penentu kualitas suatu pembelajaran secara keseluruhan. Asumsi tersebut tidak semuanya dapat dibenarkan, karena banyak sekali faktor yang menentukan kualitas pendidikan. Pendidik menjadi bagian penting dalam kebijakan terstruktur pemerintah yang mempunyai peran aktif di semua aspek pendidikan secara menyeluruh di semua tingkat pendidikan dasar dai sekolah dasar sampai dengan sekolah menengah atas/kejuruan.

Berdasarkan studi pendahuluan yang mengambil lokasi di Sekolah Menengah Kejuruan di Kota Malang ditemukan macammacam permasalahan yang nampak yaitu peserta didik belum mempunyai motivasi mengikuti pembelajaran, hal tersebut bisa diketahui dari kemunculan rasa malas yang ada di pribadi siswa jika ikut serta dalam proses pembelajaran di kelas akuntansi. Pada kelas akuntansi banyak mempelajari data berupa angka, serta perhatian peserta didik belum fokus kepada apa yang dijelaskan oleh guru. Permasalahan lain mengenai adanya penilaian kategori belum memuaskan terhadap hasil pembelajaran pada program keahlian akuntansi di Sekolah Menengah Kejuruan di Kota Malang. Guru belum sepenuhnya menjabarkan secara keseluruhan kepada siswa tentang substansi materi yang memerlukan pemahaman mendalam, akibatnya pengelolaan aktivitas pembelajaran di kelas kurang maksimal. Substansi keilmuan suatu pelajaran belum sepenuhnya dipahami yang mana harus dimiliki oleh guru pada proses pembelajaran untuk diterapkan kepada anak didik. Hal ini dikarenakan guru belum begitu memahami materi dan cara menyampaikan materi pelajaran kepada siswa. Persoalan guru banyak yang harus diselesaikan, meliputi jenjang pendidikan yang belum memadai dan kompetensi guru yang belum terselesaikan.

Tujuan dari penelitian ini pada dasarnya mengkaji motivasi belajar siswa dan pengaruhnya terhadap hasil pembelajaran akuntansi dan mengkaji kompetensi pedagogik serta pengaruhnya terhadap hasil pembelajaran akuntansi. Kompetensi pedagogik adalah kompetensi yang wajib dan harus diterapkan oleh guru. Kompetensi ini diperoleh melalui usaha belajar secara rutin dan berkelanjutan. Jadi kompetensi pedagogik menurut beberapa ahli diatas dapat diartikan sebagai kemampuan wajib yang harus diterapkan oleh pengelola kelas secara sistematis dan bertujuan mensukseskan kegiatn belajar. Berdasarkan penjelasan sebelumnya kompetensi pedagogik mempunyai makna bahwa suatu keahlian yang harus dimiliki pendidik dalam rangka pengelolaan aktivitas belajar di kelas yang melibatkan siswa sehingga dapat menentukan kesuksesan dan hasil pembelajaran peserta didik..

Untuk mendukung hasil positif dalam mencapai hasil pembelajaran yang baik maka diperlukan dukungan faktor lain yaitu motivasi. Motivasi belajar merupakan rasa yang muncul dalam diri pribadi masingmasing untuk selalu semangat belajar dan sebagai sarana untuk mengubah tingkah laku pribadinya kearah yang lebih baik dari sebelumnya. Pengertian motivasi belajar menurut Uno (2012:1) dapat dimaknai sebagai keinginan dasar yang menggerakan tingkah laku seseorang secara tetap untuk mewujudkan misi tertentu. Kesadaran dasar yang dimaksud yaitu kesadaran yang muncul untuk melakukan sesuatu yang muncul dari diri pribadi namun dapat juga keinginan dari luar yang mendukung untuk mencapai tujuannya. Bertingkah laku relatif permanen dimaksudkan agar siswa dapat secara terus menerus melakukan sesuatu secara semangat.

Sardiman (2011:75) menjabarkan motivasi sebagai keseluruhan daya penggerak yang muncul dari diri seseorang untuk beraktivitas dalam pembelajaran, sebagai jaminan dari keberlangsungan suatu kegiatan agar misi yang diinginkan dapat tercapai sesuai petunjuk yang ada di pembelajaran dalam hal ini siswa dikatakan bersemangat dalam belajar. Menurut Dimyati dan Mudjiono (2010:80) aktivitas yang didorong 
oleh kekuatan mental dalam arti perilaku manusia dalam kegiatan belajar mengajar dapat digolongkan sebagai motivasi dalam hal pembelajaran. Dorongan mental lebih mendeskripsikan dorongan yang berasal dari dalam diri individu tanpa ada keterlibatan dorongan dari luar. Menurut Safitri dan Setiyani (2016) adanya perasaan yang muncul dari diri siswa untuk mengikuti pembelajaran yang tergerak secara langsung maupun tidak langsung mengindikasikan adanya motivasi. Motivasi disini diharapkan melahirkan berbagai pengetahuan, untuk dapat dipelajari dan diterakan di semua lini kehidupan dan dapat berdampak pada diri seseorang menjadi lebih bersemangat.

Guru mempunyai pengaruh luas dalam dunia pendidikan karena guru adalah pendidik yang menjamin kualitas pendidikan dapat berjalan dengan baik sehingga guru harus memiliki kompetensi dalam mengajar. Pemenuhan akan suatu kompetensi dapat diperoleh dari berbagai latihan, pengalaman, dan pendidikan kilat yang mana dapat menunjang keahlian dalam mengajar. Sadulloh (2011) kompetensi pedagogik merupakan suatu keahlian teoritis dan praktis yang perlu benar-benar dipahami secara utuh agar keduanya dapat berjalan beriringan untuk berupaya diaplikasikan dalam pembelajaran. Kompetensi pedagogik juga membahas tentang pembentukan generasi baru yang tidak hanya membahas tentang ilmu maupun seni akan tetapi bagaimana mengembangkan karakter siswa menjadi lebih bersaing di dunia luar sejalan dengan perkembangan TIK.

$$
\text { Menurut Mulyasa (2013:75) }
$$

kompetensi pedagogik juga menciptakan pemahaman yang baik kepada siswa dalam proses belajar siswa di kelas, penilaian, evaluasi, dan tahap pengembangan untuk pengaktualisasian berbagai peluang yang ada. Pemahaman diatas serta dukungan rancangan pelaksanaan pembelajaran yang berkaitan dengan teknologi pembelajaran, evaluasi hasil pembelajaran, dan pengaktualisasikan diri merupakan bagian yang harus dimiliki seorang guru/pendidik.

Kompetensi pedagogik menurut

Wahyuningsih (2017) disebut juga sebagai kemampuan yang perlu dikembangkan dalam pembelajaran dan pemahaman akan sifat anak didik dan perkembangan belajarnya, pemahaman akan suatu konsep pendidikan, menguasai strategi pembelajaran berdasarkan pada karakteristik yang dimiliki pebelajar, serta menguasai hal-hal yang mendukung motivasi seperti diadakannya evaluasi tehadap pembelajaran baik di dalam maupun luar kelas.

Guru wajib mengetahui karakteristik peserta didik yang akan dibantu serta hal-hal yang perlu dipahami dari siswa bisa berupa perkembangan fisik dan psikisnya. Adanya pemahaman mengenai ciri-ciri anak didik, maka akan dimudahkan dalam mendiagnosa kesukaran dan kenyamanan peserta pembelajaran dan proses pengembangan dalam rangka melakukan upgrading kemampuannya. Guru diharapkan mempunyai pendekatan yang baik, memahami banyak hal berkaitan tentang psikologi anak dan perkembangannya, serta memantau kemajuannya setahap demi setahap. Bekal ilmu pengetahuan tentang pendidikan pada saat menempuh perkuliahan di Fakultas berbasis Ilmu Pendidikan mengharuskan seorang guru untuk mendalami teori-teori pendidikan khususnya ilmu psikologi tersebut, namun yang sangat penting adalah guru harus mengerti anak secara tepat di sekolah secara kongkrit. Guru harus mengetahui serta membimbing peserta didik apa yang dibutuhkan agar dapat menerima pelajaran dengan baik.

Teori kependidikan perlu juga diaplikasikan tentunya yang relevan dengan saat ini karena teori kependidikan sekarang telah berubah dengan cepat berlandaskan kemajuan berbasis teknologi, komunikasi dan informasi. Indonesia sedang mengembangkan suatu sistem kependidikan yang mengarah ke pendidikan yang berlandaskan revolusi industri 4.0. Pemahaman akan berbagai teori kependidikan oleh guru diharapkan dapat mengatasi berbagai macam persoalan dengan memilih cara terbaik sesuai situasi yang ada agar siswa dapat tumbuh kembang dengan memuaskan. Seorang pengajar harus memahami situasi konkrit siswa, serta 
harapannya guru mampu mengemas semua teori tersebut sehingga mampu menyesuaikan kondisi anak didiknya. Guru hendaknya secara rutin dan berkelanjutan menerapkan pembelajaran kontekstual.

Untuk menerapkan pembelajaran kontekstual memerlukan juga motivasi untuk mewujudkannya, sehingga motivasi sebagai sarana merubah menjadi lebih mengetahui banyak hal menjadi terpenuhi. Sardiman (2011:85) berpendapat yaitu dorongan yang muncul dalam rangka melakukan aktivitas untuk menentukan tujuan yang ingin dicapai, serta memilah perbuatan yaitu menentukan mana yang harus dikerjakan dengan tepat, dengan maksud mencapai tujuan yang diharapkan dengan menghindari aktivitas yang tidak mendukung tujuan pembelajaran dapat didefinisikan sebagai motivasi. Motivasi belajar sangat diperlukan oleh semua siswa dalam mendorong prestasi yang diharapkan oleh diri sendiri maupun sekolah sehingga tujuan pembelajaran dapat tercapai. Uno (2012:17) mendeskripsikan bahwa motivasi belajar merupakan aktivitas yang digerakkan oleh diri pribadi sesuai analisis pendahuluan yang dilakukan dengan tujuan mewujudkan tujuan nasional. Kebutuhan siswa dalam belajar yaitu siswa dapat menyerap segala sesuatu yang diberikan gurunya dan dapat mengaplikasikannya dalam kehidupan nyata sehingga maksud dan tujuan pembelajaran dapat tercapai.

Menurut Hamalik (2012) fungsi motivasi yaitu dorongan yang timbul karena perilaku atau suatu perbuatan dan juga sebagai pengarah yang artinya mengarah perbuatan dalam rangka mencapai tujuan yang diinginkan. Perbuatan siswa yang dapat mendorong timbulnya motivasi dapat berasal dari individu maupun lingkungan di sekitarnya. Dari berbagai pendapat yang ada dapat diketahui tujuan awal motivasi yaitu agar dalam proses belajar mengajar dpat dilaksanakan seingga secara tidak langsung akan berdampak pada kesuksesan dalam belajar. Hal lain yang bisa didapatkan antar lain berupa pengalaman berharga dari peristiwa yang terjadi. Belajar berhubungan dengan perubahan yang terjadi pada individu yang didapatkan dari pengalaman di lingkungannya. Untuk mengetahui perubahan yang terjadi berkaitan dengan prestasi belajar yang dicapai maka perubahan yang dialami tersebut pasti terdapat faktor-faktor yang mempengaruhinya.

Menurut Baharudin (2012) faktor internal dan faktor eksternal memegang peranan penting dalam menentukan suatu hasil akhir. Faktor internal dapat didefinisikan sebagai kondisi sebenarnya dari lahiriah dan batiniah dari peserta didik yang dapat digolongkan ke dalam dua perspektif yaitu aspek fisiologis dan psikologis. Karakteristik yang muncul dari aspek fisiologis yang dapat dilihat, diantaranya kondisi jasmani/lahiriah secara umum dan tegangan pada otot sebagai tanda tingkat kebugaran bagian-bagian tubuh dan sendi, sehingga antusiasme siswa dalam mengikuti pelajaran menjadi meningkat sehingga menjadi lebih bersemangat. Menurut aspek psikologis, kuantitas serta kualitas pembelajaran dapat diketahui mudah diketahui jika mengetahui faktor-faktor yang ada muncul ke permukaan. Selain faktor fisiologis dan psikologis, terdapat faktor batiniah yang menurut masyarakat pada umumnya dipandang lebih penting. Adapun faktor-faktor tersebut adalah kecerdasan intelektual, emosional siswa, bakat dan minat siswa.

Kemampuan yang berkaitan dengan psikofisik untuk membangkitkan keinginan dalam upaya beradaptasi dengan langkah yang benar dapat disebut sebagai kecerdasan intelektual atau intelegensi. Persoalan otak bukan hanya masalah intelegensi saja, akan tetapi juga bagian dari membaca kualitas bagian tubuh lain. Peran organ tubuh lain merupakan bagian yang penting serta hal yang menonjol berupa peran otak kaitannya dengan intelegensia, karena hampir seluruh aktivitas manusia dikendalikan oleh otak. Sementara itu kecerdasan emosional lebih menekankan bagaimana siswa dapat bersikap dan mengekspresikan segala sesuatunya dengan bijak dalam menghadapi suatu hal.

Sikap siswa merupakan ranah yang berdimensi afektif yang dapat bermakna positif maupun bermakna negatif. Secara 
psikologis, sikap berperan penting dalam kesuksesan belajar. Pembelajaran yang disertai dengan sikap positif perlu ditanamkan, hal ini juga berlaku materi pembelajaran yang diberikan guru, dan pergaulan di lingkungannya seperti keadaan ruang, kawan sejawat, sarana dan prasarana pembelajaran. Siswa juga harus mempunyai bakat sebagai bekal kemampuan potensial untuk mencapai kesuksesan di masa mendatang. Bakat yang dipunyai oleh masing-masing siswa mempunyai kecenderungan dapat diasah untuk mejadi pribadi yang sukses.

Disamping bakat maka perlu didukung oleh minat. Minat dapat didefinisikan sebagai keinginan yang kuat terhadap sesuatu yang secara tidak langsung dapat meningkatkan hasil yang berkualitas pada pembelajaran di berbagai bidang yang dipelajari. Faktor luar terdiri dari faktor lingkungan dan faktor instrumental. Faktor lingkungan siswa ini digolongkan ke dalam dua bagian yaitu faktor lingkungan alam dan sosial. Yang termasuk faktor lingkungan alam adalah kondisi suhu, kelembaban udara, waktu, dan lokasi gedung sekolah. Proses pembelajaran serta hasilnya dipengaruhi juga oleh faktor lingkungan sosial baik berupa budaya, manusia dan representasinya. Alat pembelajaran, peralatan fisik di kelas, kurikulum belajar, media pembelajaran, serta strategi belajar mengajar termasuk faktor instrumental yang digunakan guru untuk memperlancar aktivitas pembelajaran siswa. Berdasarkan penjelasan sebelumnya, keberhasilan suatu hasil pembelajaran ditentukan melalui faktor internal dan faktor eksternal yang keduanya saling berkaitan.

Nilai akhir yang disusun oleh guru dapat menggambarkan seberapa besar ketercapaian aspek pengetahuan, aspek sikap, dan aspek keterampilan yang tertera pada suatu pelajaran tertentu. Pendidik dapat melakukan pengukuran terkait pencapaian kemampuan siswa dengan mengetahui dari hasil belajar siswa yang didapat sehingga hasil tersebut akan dimasukkan dalam rapor. Menurut Purwanto (2010:2) hasil pembelajaran yang dicapai oleh peserta didik menunjukkan tingkat kematangan dan pencapaian siswa dalam mewujudkan tujuan belajar. Belajar merupakan suatu yang wajib ditempuh prosesnya dan sukses atau tidak peserta didik dalam berproses di bidang pendidikan tergantung pada lingkungan dan siswanya itu sendiri. Dari berbagai pendapat tentang hasil pembelajaran maka dapat didefinisikan sebagai pencapaian yang diterima pebelajar setelah menerima pelajaran pada kegiatan belajar mengajar dan menunjukkan tingkat kemajuan siswa dalam belajarnya.

\section{METODE}

Jenis penelitian yang diambil menggunakan pendekatan explanatory reasearch. Lokasi riset bertempat di Sekolah Menengah Kejuruan di Kota Malang. Rentang waktu pengambilan data berlangsung 1 (satu) semester di tahun pelajaran 2017-2018. Data hasil pembelajaran yang diolah dalam data yaitu nilai ujian akhir semester. Populasi yang ditentukan yaitu keseluruhan siswa yang menempuh mata pelajaran akuntansi di sekolah menengah atas di Kota Malang dengan total sejumlah 144 siswa. Data utama yang diambil berasal dari motivasi belajar siswa dan kompetensi pedagogik guru.

Data dikumpulkan dengan berbagai cara yaitu didapatkan dari dokumentasi dan pengisian kuisioner oleh responden. Menurut Sugiyono (2011) metode dokumentasi yaitu mengambil nilai Ujian Akhir Semester dan metode kuesioner digunakan untuk mengambil data tentang kompetensi pedagogik dan hasil pembelajaran. Selanjutnya setelah tahap pengumpulan maka data perlu dianalisis lebih lanjut dengan pendekatan descriptive analysis dan inferential analysis.

Berikut rekapitulasi populasi pada riset ini digambarkan berikut ini.

Tabel 1. Populasi

\begin{tabular}{ccc}
\hline No & Class & Population \\
\hline 1 & X A & 36 \\
2 & X B & 36 \\
3 & X C & 36 \\
4 & X D & 36 \\
\hline \multicolumn{2}{c}{ Jumlah } & 144 \\
\hline
\end{tabular}


Penelitian ini termasuk penelitian sampel karena pengambilannya dilakukan dengan menggunakan teknik random yaitu teknik pengambilan sampel dilakukan secara acak denga syarat jika populasi memiliki anggota atau berunsur strata proporsional. Sampel dapat diketahui dari rumus Slovin yaitu.

$\mathrm{n}=$ populasi kelas $\mathrm{x}$ jumlah sampel ditentukan jumlah keseluruhan populasi

Tabel 2. Sampel

\begin{tabular}{lll}
\hline No & \multicolumn{1}{c}{ Kelas } & Jumlah \\
\hline 1 & Kelas X A & 9 siswa \\
2 & Kelas X B & 9 siswa \\
3 & Kelas X C & 9 siswa \\
4 & Kelas X D & 9 siswa \\
& Jumlah & 36 siswa \\
\hline
\end{tabular}

Rancangan penelitian ini dapat dilihat sebagai berikut.

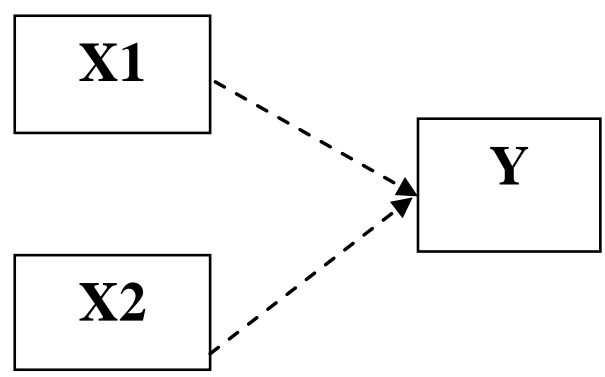

Penjelasan :

$\mathrm{X}_{1} \quad$ : Motivasi belajar

$\mathrm{X}_{2} \quad$ : Kompetensi Pedagogik

$\mathrm{Y}$ : Hasil pembelajaran

Adapun instrumen dalam penelitian ini berupa kisi-kisi angket. Kisi-kisi berikut dapat dilihat terdiri dari variabel serta indikatornya.

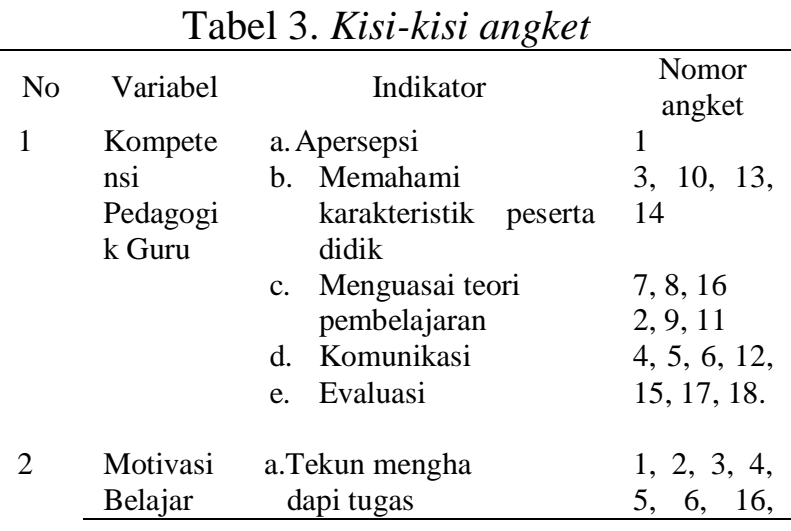

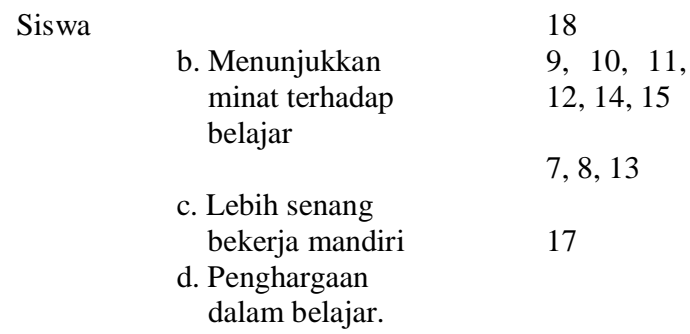

Adapun jawaban dari item kuesioner dinilai dengan empat skala pengukuran sebagai berikut:
a. Untuk "selalu" = nilai 5
b. Untuk "sering" = nilai 4
c. Untuk "kadang-kadang" = nilai 3
d. Untuk "jarang" = nilai 2
e. Untuk "tidak pernah" = nilai 1

\section{HASIL DAN PEMBAHASAN}

Setelah data diperoleh dan dikumpulkan maka didapatkan skor untuk setiap variabel yaitu skor tersebut didapatkan dari hasil pengisian angket dua variabel independen meliputi motivasi hasil pembelajaran dan kompetensi pedagogik serta dampaknya terhadap hasil pembelajaran.

\section{Kajian Deskriptif}

Penyebaran kuesioner yang berasal dari responden menghasilkan data yang menggambarkan hasil analisis deskriptif dari variabel independen pertama dalam penelitian ini yaitu kompetensi pedagogik guru akuntansi. Berikut ini hasil analisis deskriptif dari kompetensi pedagogik guru akuntansi yang dapat dicermati.

Tabel 4. Kompetensi Pedagogik

\begin{tabular}{lcccccc}
\hline & \begin{tabular}{c} 
N \\
\cline { 2 - 7 }
\end{tabular} & $\begin{array}{c}\text { Rang } \\
\text { e }\end{array}$ & $\begin{array}{c}\text { Mini } \\
\text { mum }\end{array}$ & $\begin{array}{c}\text { Maxi } \\
\text { mum }\end{array}$ & \multicolumn{2}{c}{ Mean } \\
\cline { 2 - 7 } & $\begin{array}{c}\text { Statis } \\
\text { tic }\end{array}$ & $\begin{array}{c}\text { Statis } \\
\text { tic }\end{array}$ & $\begin{array}{c}\text { Statis } \\
\text { tic }\end{array}$ & $\begin{array}{c}\text { Statis } \\
\text { tic }\end{array}$ & $\begin{array}{c}\text { Statisti } \\
\text { c }\end{array}$ & $\begin{array}{c}\text { Std. } \\
\text { Error }\end{array}$ \\
$\begin{array}{l}\text { Komp_ } \\
\text { peda }\end{array}$ & 36 & 21 & 55 & 76 & 63,38 & 1,239 \\
Valid N & & & & & & \\
(listwis & 36 & & & & & \\
e) & & & & & &
\end{tabular}

Berdasarkan hasil analisis tentang kompetensi pedagogik guru dengan jumlah responden sebanyak 36 siswa dan rentangnya ditemukan 21 yang dihitung dari nilai paling rendah 55 dan nilai paling tinggi 76 serta 
diketahui rata-rata nilainya 63,38 sementara error standard menunjukkan angka 1,239. Berdasarkan penjelasan diatas dapat dikatakan bahwa nilai rata-rata (mean) sebesar 63,38 diperoleh dari nilai terendah 55 dan nilai tertinggi 76 . Sementara itu, hasil variabel lain yaitu motivasi belajar siswa dapat digambarkan dalam tabel dibawah ini. Berikut hasil analisis dari motivasi belajar siswa.

Tabel 5. Motivasi Belajar

\begin{tabular}{lccccccc}
\hline & $\begin{array}{c}\text { N } \\
\end{array}$ & $\begin{array}{c}\text { Rang } \\
\text { e }\end{array}$ & $\begin{array}{c}\text { Minim } \\
\text { um }\end{array}$ & $\begin{array}{c}\text { Maxi } \\
\text { mum }\end{array}$ & \multicolumn{2}{c}{ Mean } \\
\cline { 2 - 7 } & $\begin{array}{l}\text { Sta } \\
\text { tisti } \\
\text { c }\end{array}$ & $\begin{array}{c}\text { Statis } \\
\text { tic }\end{array}$ & $\begin{array}{c}\text { Statisti } \\
\text { c }\end{array}$ & $\begin{array}{c}\text { Statis } \\
\text { tic }\end{array}$ & $\begin{array}{c}\text { Statisti } \\
\text { c }\end{array}$ & $\begin{array}{c}\text { Std. } \\
\text { Error }\end{array}$ \\
Motiva & 36 & 27 & 53 & 80 & 68,80 & 1,128 \\
si_bljr & 36 & & & & & & \\
$\begin{array}{l}\text { Valid N } \\
\text { (listwis }\end{array}$ & 36 & & & & & \\
e) & & & & & & \\
\hline
\end{tabular}

Seusai data berhasil diolah, langkah selanjutnya data itu dicoba dideskripsikan dan hasilnya bahwa variabel motivasi pembelajaran diketahui jumlah responden sejumlah 36 orang dari rentang 27 yang didapatkan dari nilai terendah sebesar 53 dan nilai tertinggi sebesar 80, serta didapatkan nilai rata-rata sebesar 68,80 sedangkan error standard didapatkan 1,128. Analisis deskriptif terakhir mengenai hasil pembelajaran siswa. Berikut ini hasil analisis deskriptif dari hasil pembelajaran siswa. Jika dilihat dari nilai standar error untuk masing-masing variabel baik kompetensi pedagogik guru akuntansi maupun motivasi belajar siswa diketahui bahwa mempunya nilai yang relatif kecil. Nilai standar error untuk kompetensi pedagogik sebesar 1,239 dan motivasi belajar siswa sebesar 1,128 menunjukkan bahwa sampel yang dipilih sudah terwakili atau dapat dikatakan memenuhi persyaratan yang telah ditentukan.
Tabel 6. Hasil pembelajaran

\begin{tabular}{lccccccc}
\hline & N & Range & $\begin{array}{c}\text { Minimu } \\
\mathbf{m}\end{array}$ & $\begin{array}{c}\text { Maxi } \\
\text { mum }\end{array}$ & \multicolumn{2}{c}{ Mean } \\
& $\begin{array}{r}\text { Stat } \\
\text { istic }\end{array}$ & $\begin{array}{c}\text { Statist } \\
\text { ic }\end{array}$ & Statistic & $\begin{array}{c}\text { Statist } \\
\text { ic }\end{array}$ & Statistic & $\begin{array}{c}\text { Std. } \\
\text { Error }\end{array}$ \\
& & & & & & & \\
Hasil_blj & 36 & 16 & 80 & 96 & 89,78 &, 691 \\
r & & & & & & \\
$\begin{array}{l}\text { Valid N } \\
\text { (listwise }\end{array}$ & 36 & & & & & \\
) & & & & & & & \\
\hline
\end{tabular}

Deskripsi hasil pembelajaran siswa didapatkan dengan melihat nilai ujian akhir semester tahun akademik 2017-2018 pada siswa program keahlian akuntansi dapat dijabarkan berdasarkan analisis statistik dengan menggunakan statistik deskriptif seperti pada keterangan berikut.

Tabel 7. Frekuensi hasil pembelajaran siswa

\begin{tabular}{|c|c|c|c|}
\hline No & Nilai Tes & Frek. & $\%$ \\
\hline 1. & 80 & 3 & $8,33 \%$ \\
\hline 2. & 85 & 4 & $11,11 \%$ \\
\hline 3 & 87 & 1 & $2,78 \%$ \\
\hline 4 & 89 & 3 & $8,33 \%$ \\
\hline 5 & 90 & 11 & $30,56 \%$ \\
\hline 6 & 91 & 1 & $2,78 \%$ \\
\hline 7 & 92 & 3 & $8,33 \%$ \\
\hline 8 & 93 & 4 & $11,11 \%$ \\
\hline 9 & 94 & 2 & $5,56 \%$ \\
\hline 10 & 95 & 3 & $8,33 \%$ \\
\hline \multirow[t]{2}{*}{11} & 96 & 1 & $2,78 \%$ \\
\hline & Jumlah & 36 & $100 \%$ \\
\hline
\end{tabular}

Hasil perhitungan untuk nilai ujian menyatakan bahwa nilai tertinggi diperoleh 11 oleh responden, sedangkan nilai ujian terendah sejumlah 3 responden. Jika diamati kembali angka-angka yang terlihat di kumpulan hasil pembelajaran melibatkan responden sejumlah 36 siswa, ditemukan rentang sebanyak 16 yang didapatkan dari nilai terendah 80 dan paling tinggi 96 maka dapat dideskripsikan nilai rata-ratanya sejumlah 89,77 sementara itu angka deviation standard berada pada kisaran 0,692. Berdasarkan perhitungan statistik dapat diterjemahkan bahwa hasil pembelajaran siswa pada program keahlian akuntansi sekolah menengah kejuruan di Kota Malang pada mata ajar akuntansi tergolong baik, sebagai bukti dapat dilihat kembali nilai rataratanya 89,78. Apabila nilai tersebut 
diperbandingkan dengan standar minimal yang telah ditetapkan, yang disebut sebagai Ketuntasan Minimal maka nilai pembelajaran akuntansi sebagian besar memperoleh nilai lebih dari 75. Hal tersebut menunjukan bahwa siswa telah melewati pembelajaran dengan sukses dan lulus.

\section{Analisis Regresi Berganda}

Analisis data sangat diperlukan untuk mengetahui kebermanfaatan informasi yang didapatkan. Arikunto (2010) menyatakan berbagai teknik analisis data sangat diperlukan dalam penelitian, namun dalam penelitian ini yang dirasa cocok menggunakan regresi berganda. Adapun persamaannya:

$\mathrm{Y}:$ Hasil pembelajaran

$\mathrm{X}_{1}$ : Motivasi belajar

$\mathrm{X}_{2}$ : Kompetensi pedagogik

b : Koefisien regresi

a : Nilai Konstan

Hasil pengolahan data dari analisis regresi berganda dapat digambarkan berikut.

Tabel 8. Coefficient

\begin{tabular}{lrrccc}
\hline \multicolumn{1}{c}{ Model } & \multicolumn{1}{c}{ B } & Std Error & Beta & t & Sig. \\
\hline Constant & 98.850 & 16.465 & & 6.048 & .000 \\
Pedagogik & .377 & .164 & .330 & 2.209 & .034 \\
Motivasi & .345 & .090 & .369 & 2.469 & .019 \\
\hline
\end{tabular}

Dengan memperhatikan tabel di bagian coefficient yang telah dianalisis dengan regresi berganda dapat diketahui bahwa nilai konstan pada kisaran sebesar 98,850 sedangkan nilai variabel motivasi belajar ditemukan sebesar 0,345 dan nilai variabel kompetensi pedagogik dapat diketahui sebesar 0,377 serta maka apabila diformulasikan akan diperoleh persamaan berikut ini :

$$
Y=98,850+0,345 X_{1}+0,377 X_{2}
$$

Setelah persamaan diketahui maka perlu diketahui makna dari adanya peningkatan kompetensi pedagogik guru sebesar satu persen, maka hasil pembelajaran siswa juga akan meningkat satu persen. Adanya peningkatan kompetensi pedagogik guru sebesar satu tingkat, maka hasil pembelajaran siswa akan meningkat sebesar 0,377 kali dan motivasi belajar siswa meningkat persentasenya sama dengan variabel sebelumnya, maka hasil pada pembelajaran juga meningkat sejumlah 0,345 kali. Sedangkan konstanta 98,850 artinya jika kedua variabel bebas bernilai 0 maka hasil pembelajaran siswa bernilai 98,850 .

Tabel 9. Nilai Anova

\begin{tabular}{llllll}
\hline Model & $\begin{array}{l}\text { Sum of } \\
\text { Square }\end{array}$ & $\begin{array}{l}\text { Mean } \\
\text { Square }\end{array}$ & F & Sig. \\
\hline Regresi & 162.606 & 2 & 81.303 & 6.103 & .006 \\
Residu & 439.616 & 33 & 13.322 & & \\
Total & 602.222 & 35 & & & \\
\hline
\end{tabular}

Hasil perhitungan anova telah diketahui dan diperoleh $\mathrm{F}$ hitung senilai 6,103, sementara F tabelnya yaitu 2,87 sehingga secara matematis dapat ditulis 6,103 $>$ 2,87 dengan memakai taraf signifikansi 0,05 maka dapat dimaknai bahwa motivasi pembelajaran dan kompetensi yang dimiliki guru berdampak pada hasil pembelajaran akuntansi keuangan. Sementara itu pada kolom Sig menunjukkan angka pada 0,006 yang berarti bahwa nilai signifikannya dibawah 0,05 yang dapat diartikan bahwa terdapat pengaruh yang sangat signifikan variabel independen pertama yaitu kompetensi guru akuntansi dan variabel independen kedua yaitu motivasi belajar siswa terhadap hasil pembelajaran pada mata ajar akuntansi keuangan.

Tabel 10. Model summary

\begin{tabular}{llll}
\hline Model & R & R Square & Adjusted R Square \\
\hline 1 & .725 & .525 & .510 \\
\hline
\end{tabular}

Berdasarkan data model summary itu menunjukkan bahwa R square sebesar 0,525. nilai determinasi atau sumbangan keefektifan sebesar $0,525(52,5 \%)$ artinya 2 variabel yaitu kompetensi pedagogik guru dan motivasi belajar memiliki sumbangan keefektifan senilai 52,5\% (dampak/implikasi) sisanya $47,5 \%$ dipengaruhi oleh faktor tertentu. Oleh sebab itu, kontribusi variabel $\mathrm{X}$ maupun varibel $\mathrm{Y}$ dalam penelitian ini adalah 52,5 artinya $47,5 \%$ atau 0.475 hasil pembelajaran akuntansi keuangan bisa disebabkan oleh fakto-faktor diluar analisis ini. 


\section{Kompetensi pedagogik berpengaruh terhadap hasil pembelajaran akuntansi keuangan}

Kompetensi pedagogik guru Akuntansi di sekolah menengah kejuruan Kota Malang dapat dilihat dari sisi variasi cara yang dilakukan penyampaian materi, serta kreativitas guru untuk menggunakan berbagai cara dalam proses pembelajaran. Guru dalam pelaksanaan proses pembelajaran membuat persiapan pengajaran sesuai dengan muatan kurikulum dan tujuan yang hendak dicapai setiap kali pelaksanaan kegiatan belajar mengajar. Secara umum, metode dalam proses pembelajaran masih dominasi dengan metode ceramah, kemudian dikembangkan dengan diskusi (tanya jawab), dan belum menggunakan observasi (pengamatan), serta praktikum.

Dengan melihat data hasil olahan yang telah dilakukan disana kita dapat mengetahui kompetensi pedagogik berpengaruh terhadap hasil pembelajaran yang didapat siswa program keahlian akuntansi di mata pelajaran akuntansi keuangan. Jika ditelusuri lebih dalam maka koefisien beta dapat diketahui dan bernilai 0,0362 telah menunjukkan pengaruh diantara variabel independen dengan variabel dependennya. Hal ini dapat juga dikatakan sebagai hal yang positif dan dikategorikan semakin baik. Sebaiknya jika negatif pengaruhnya maka juga bisa dikatakan semakin kurang baik. Siswa pasti akan termotivasi untuk melakukan kegiatan pembelajaran dan memperbaiki hasil pembelajarannya jikalau ada pengaruh variabel yang positif pula. Hasil penelitian ini tentunya sesuai dengan riset terdahulu yang disampaikan Umami dan Roesminingsih (2014) dengan hasil penelitian yaitu hasil pembelajaran siswa secara kognitif dipengaruhi kompetensi pedagogik, secara nyata uji t menghasilkan angka sebesar 3,013 dengan taraf signifikansi alfa kurang dari $5 \%$. Hasil dilapangan menunjukkan kompetensi pedagogik berkontribusi terhadap variabel dependen hasil pembelajaran yang dicapai oleh siswa sebesar $15,9 \%$.
Kesiapan seorang guru dalam mempersiapkan proses belajar dan mengajar sangatlah diperlukan. Hal ini sangat berkorelasi positif dengan hasil pembelajaran siswa di kelas. Irianto (2015) menyebutkan bahwa kemampuan pedagogik guru juga harus dibekali dengan kemampuan teknologi informasi. Hal ini diperlukan dalam rangka menghadapi revolusi industri 4.0 yang mana segala sesuatunya serba digital. Perpaduan kompetensi yang dimiliki oleh guru dengan teknologi informasi dapat menjadi tolok ukur kesuksesan dalam proses belajar mengajar. Menurut Putri (2017) kompetensi pedagogik berbicara tentang pemahaman akan wawasan dan landasan utama dan mendasar dalam kependidikan, memiliki kemampuan mengorganize proses pembelajaran, memiliki kesepahaman tentang siswa, pengembangan kurikulum, desain operasional pembelajaran, evaluasi terhadap pembelajaran, dan pengembangan demi kemajuan pebelajar.

\section{Motivasi belajar berpengaruh terhadap hasil pembelajaran akuntansi keuangan}

Pelaksanaan kegiatan observasi di lapangan menunjukan motivasi belajar yang dipunyai siswa belum maksimal hal ini dikarenakan kegiatan belajar mengajar siswa masih terlalu pasif dan belum terlibat secara maksimal dalam proses belajar di kelas. Sedikitnya siswa yang bertanya ketika diberi kesempatan bertanya dan sedikitnya siswa akan menjawab ketika ada pertanyaan dari guru. Berdasarkan jawaban angket hanya sedikit siswa yang menyatakan aktif mengikuti diskusi apabila dilaksanakan diskusi selama pelajaran akuntansi dan sedikit siswa yang rajin mencari literatur yang terkait dengan materi pembelajaran, hal tersebut terbukti adanya sebagian besar peserta didik tak memiliki buku penunjang dan siswa hanya terpaku pada buku LKS dari sekolah. Peserta didik cenderung menunggu atau menerima apa yang diajarkan guru. Belajar dari bukubuku penunjang masi sangat terbatas.

Hasil penelitian yang ada membuktikan adanya pengaruh variabel independen motivasi belajar terhadap hasil pembelajaran siswa. Jika dirunut hasil 
koefisien beta maka ditemukan nilainya sebesar 0,345 yang berarti menunjukkan hubungan searah antara motivasi terhadap hasil pembelajaran. Hubungan searah berlaku dikarenakan jika motivasi bernilai baik maka hasil pembelajaran juga baik begitupun sebaliknya. Penelitian ini diperkuat dengan paparan dari Andartari, Susanti, dan Andriani (2013) yang menekankan adanya hubungan positif antara variabel motivasi dengan hasil pembelajaran. Penelitian yang relevan serta mendukung hasil riset yaitu yang dikemukakan oleh Mappeasse (2009:6) menguraikan bahwa hasil pembelajaran PLC siswa bernilai positif dikarenakan adaya dukungan dari motivasi. Widoyoko dan Rinawati (2012:8) penguasaan materi pembelajaran yang disampaikan guru mempunyai dampak sekitar 5\% terhadap variasi motivasi belajar siswa, artinya semakin tinggi guru dalam menguasai materi pelajaran akan semakin meningkatkan motivasi belajar siswa yang pada akhirnya hasil pembelajaran siswa juga meningkat. Hasil tersebut berbanding lurus dengan yang disampaikan oleh Uno (2012:27) motivasi yang tepat akan membawa pada hasil pembelajaran yang memuaskan. Dengan adanya rasa kepuasan yang didapat siswa maka akan meminimalisasi kegagalan dalam belajar. Kegagalan belajar dapat berasal dari guru maupun siswa tesebut. Kegagalan yang berasal dari guru bisa disebabkan karena tidak adanya motivasi, sehingga guru wajib memberi motivasi ke anak didiknya.

Perubahan energi yang ada pada diri manusia bisa disebabkan oleh motivasi, yang mana berhubungan dengan gejala seseorang ingin segera mewujudkan apa yang menjadi cita-citanya yang terpendam dalam benak pribadi. Ciri-ciri motivasi melekat pada setiap manusia itu dapat mudah diketahui yaitu tekun menghadapi tugas, ulet menghadapi kesulitan, untuk berprestasi tidak memerlukan sokongan dari luar, adanya minat terhadap sesuatu, sangat senang bekerja, aktif mencari dan memberi solusi atas pemasalahan, teguh mempertahankan pendapat, tidak gampang melepaskan hal yang diyakini. Seseorang yang telah memilki ciri seperti diatas, berarti termasuk pribadi yang punya aura positif dalam memotivasi diri. Karakter yang telah dikemukakan sebelumnya penting untuk ditanamkan agar dalam proses pembelajaran siswa menjadi lebih percaya diri, optimis, tekun, ulet, rajin, dan bertanggung jawab kepada apa yang menjadi kewajibannya. Motivasi yang kuat dalam belajar akan menelurkan kesuksesan dalam belajar. Makna lain yang dapat ditangkap yaitu dengan adanya dorongan yang baik, pebelajar termotivasi untuk terus berkarya sehingga menjadi kebanggaan semua orang. Tingkat pencapaian hasil pembelajarannya dapat ditunjukkan dari intensitas motivasi seorang siswa. Dengan demikian penelitian ini searah teori-teori di atas dengan dan searah dengan riset sebelumnya yang pernah dilaksanakan Wulandari (2015) dengan hasil penelitian terdapat pengaruh yang positif antara motivasi pembelajaran terhadap hasil pembelajaran.

\section{Dampak yang ditimbulkan dari motivasi belajar dan kompetensi pedagogik terhadap hasil belajar}

Purwanto (2010:102) menyebutkan hasil pembelajaran yang didapat siswa tidak lain karena faktor individu. Faktor individu terdiri atas kematangan, kecerdasan, latihan, motivasi, dan sifat-sifat pribadi. Faktor lain yang berpengaruh adalah faktor sosial terdiri atas keluarga, guru, cara mengajar, fasilitas belajar, lingkungan dan kesempatan yang tersedia. Motivasi belajar adalah kekuatan mental yang menjadi penggerak untuk melakukan kegiatan belajar, sehingga diharapkan dapat mencapai prestasi yang diharapkan, dengan begitu usaha yang dijalankan akan semakin menunjukkan hasil yang baik. Berdasarkan hasil tersebut dapat mengindikasikan terdapat pengaruh diantara veriabel independen dan dependennya bagi siswa di sekolah menengah kejuruan di Kota Malang. Angka R sebesar 0,725 menunjukkan bahwa pengaruh variabel bebas terhadap variabel terikat yaitu kuat karena angka tersebut berada di atas 0,5. Jika terjadi kenaikan pada kedua variabel independen maka akan terjadi kenaikan pula pada hasil pembelajaran. 
Besar adjusted $R$ square adalah 0,510, hal ini berarti 51,0 \% perubahan variabel terikat hasil pembelajaran siswa disebabkan oleh variabel motivasi belajar dan kompetensi pedagogik sedangkan sisanya $49 \%$ disebabkan oleh faktor diluar perubahan variabel motivasi belajar siswa dan kompetensi pedagogik. Variabel-variabel lain di luar penelitian ini meliputi sarana belajar yang disediakan sekolah, fasilitas pembelajaran di rumah, kondisi ekonomi keluarga, dan perhatian dari orang tua.

Berdasarkan nilai koefisien regresi

$$
\mathrm{Y}=98,850+0,345 \mathrm{X} 1+0,377 \mathrm{X} 2
$$

bahwa dari persamaan tersebut variabel dengan koefisien yang lebih besar berarti akan menimbulkan dampak yang besar pula. Dengan demikian kompetensi pedagogik guru dalam penelitian ini memberikan pengaruh yang lebih besar dibandingkan dengan motivasi belajar karena nilai koefien regresinya sebesar 0,362. Dengan demikian dapat dimaknai bahwa motivasi pembelajaran dan kompetensi pedagogik mempunyai dampak pada hasil pembelajaran siswa.

\section{KESIMPULAN}

Hasil yang telah diperoleh sekaligus pembahasan yang dibuat maka dapat dimaknai adanya dampak sangat positif antara kompetensi pedagogik dan hasil pada pembelajaran akuntansi yang dalam hal ini juga telah didukung oleh penelitian terdahulu. Sementara itu, dampak motivasi belajar siswa akan hasil pembelajaran akuntansi keuangan juga sangat baik yang berari semua varibel mengindikasikan keberlakuannya dan mempunyai hubungan positif. Hal ini juga telah diperkuat oleh artikel-artikel ilmiah sebelumnya. Saran bagi guru akuntansi yaitu memperbaiki keprofesionalannya dalam menguasai kompetensi pedagogik sebagai upaya untuk meningkatkan kapasitas dan integritas seorang guru.

Keterbatasan dalam penelitian ini yaitu berdasarkan analisis deskriptif terdapat perbedaan antara motivasi belajar dan kompetensi pedagogik terhadap hasil pembelajaran. Kedua variabel tersebut dikategorikan termasuk sedang, sebaliknya hasil pembelajaran tergolong baik. Hal tersebut dikarenakan pertanyaan dalam angket yang kurang cocok dengan kondisi siswa atau responden yang beragam. Saran untuk penelitan selanjutnya yaitu guru hendaknya memberikan bimbingan dan motivasi kepada siswa tentang pentingnya belajar, guru diharapkan dapat menciptakan kegiatan belajar yang menarik dengan cara menerapkan metode pembelajaran kooperatif dan berbasis pembelajaran kontekstual yang menggabungkan teori dengan praktik.Siswa hendaknya meningkatkan motivasi belajarnya dengan aktif dengan aktif mengerjakan semua bentuk tugas dari gurunya.

\section{DAFTAR PUSTAKA}

Andartari., Susanti, S., \& Andriani, V. 2013. "Pengaruh Kemampuan Intelektual (IQ) dan Motivasi Belajar Terhadap Hasil pembelajaran Siswa Pada Mata Pelajaran Akuntansi Pada SMA Labschool Rawamangun". Jurnal Pendidikan Ekonomi dan Bisnis, Vol.1 No. 1 : 18-30.

Arikunto. 2010. Statistika untuk Penelitian. Jakarta : Bumi Aksara.

Baharudin. 2012. Teori Belajar dan Pembelajaran. Jogjakarta: Ar-Ruz Media.

Dimyati \& Mudjiono, P. 2010. Belajar dan Pembelajaran. Jakarta: Rineka Cipta.

Hamalik, Oemar. 2012. Psikologi Belajar \& Mengajar. Bandung: Sinar Baru Algesindo.

Hamdu, Ghullam \& Agustina, Lisa. 2011. "Pengaruh Motivasi Belajar Siswa Terhadap Prestasi Belajar IPA Di Sekolah Dasar". Jurnal Penelitian Pendidikan, Vol.12 No.1: 81-86.

Irianto. 2015. "Pengaruh Kompetensi Pedagogik, Profesional, Kepribadian, 
dan Sosial Yang Dimiliki Dosen Terhadap Hasil pembelajaran Mahasiswa". Jurnal Bisnis dan Kewirausahaan, Vol.11 No.1: 46-58.

Mappeasse, Muh. Yusuf. 2009. "Pengaruh Cara dan Motivasi Belajar Terhadap Hasil pembelajaran Programmable Logic Controller (PLC) Siswa Kelas III Jurusan Listrik SMK Negeri 5 Makassar". Jurnal Medtek, Vol.1 No.2: 1-6.

Mulyasa. 2013. Standar Kompetensi dan Sertifikasi Guru. Bandung: Remaja Rosdakarya.

Nursyaidah. 2015. "Gaya Mengajar Guru Terhadap Motivasi Belajar Siswa". Jurnal Thariqah Ilmiah, Vol. 02 No. 02: 110-120.

Purwanto. 2010. Evaluasi Hasil pembelajaran. Surakarta: Pustaka Pelajar.

Putri, Santina Dwi. 2017. "Pengaruh Kompetensi Pedagogik dan Kompetensi Sosial Terhadap Prestasi Belajar Siswa Pada Mata Pelajaran Pengantar Administrasi Perkantoran Kelas X Administrasi Perkantoran di SMK Negeri 1 Subang”. Jurnal Pendidikan Manajemen Perkantoran, Vol. 1 No. 1: 9-18.

Putri, Dinar Tiara Nadip \& Isnani, Gatot. 2015. "Pengaruh Minat dan Motivasi Terhadap Hasil pembelajaran Pada Mata Pelajaran Pengantar Administrasi Perkantoran". Jurnal Pendidikan Bisnis dan Manajemen, 118-124.

Sadulloh, Uyoh. 2011. Pedagogik (Ilmu Mendidik). Bandung: Alfabeta.

Safitri, Merdiana Era \& Setiyani, Rediana. 2016. "Pengaruh Motivasi Belajar, Computer Attitude, dan Fasilitas
Laboratorium Akuntansi Terhadap Prestasi Belajar Komputer Akuntansi MYOB". Economic Education Analysis Journal, Vol. 5 No. 1: 30-43.

Sardiman. 2011. Interaksi dan Motivasi Belajar. Jakarta: PT Raja Grafindo Persada.

Sugiyono. 2011. Metode Penelitian Kuantitatif, Kualitatif, dan R\&D. Bandung: Alfabeta.

Umami, Dody Rijal \& Roesminingsih, Erny. 2014. "Pengaruh Kompetensi Pedagogik dan Motivasi Kerja Guru Terhadap Prestasi Belajar Siswa Dalam Ujian Nasional (UN) di SMA Negeri Se Kota Mojokerto". Jurnal Inspirasi Manajemen Pendidikan, Vol.3 No.3: 81-88.

Uno, Hamzah. B. 2012. Teori Motivasi \& Pengukurannya. Jakarta: Bumi Aksara.

Wahyuningsih, Roy. 2017. "Pengaruh Kompetensi Pedagogik dan Kompetensi Profesional Guru Terhadap Motivasi Belajar Siswa Pada Mata Pelajaran Ekonomi di MAN 5 Jombang". Jurnal Pendidikan Ekonomi, Kewirausahaan, Bisnis, dan Manajemen, Vol. 1 No. 1: 19-29.

Widoyoko, S. Eko Putro \& Rinawati, Anita. 2012. "Pengaruh Kinerja Guru Terhadap Motivasi Belajar Siswa". Cakrawala Pendidikan, Th. XXI, No. 2: 278-289.

Wulandari, Denik. 2013. "Pengaruh Kompetensi Pedagogik dan Kompetensi Profesional Guru Terhadap Economic Literacy Melalui Prestasi Belajar Siswa Kelas XII IPS di SMA Kota Malang". Jurnal Pendidikan Humaniora, Vol.1 No.1: 25-29. 
Wulandari, Ruri Nurul Aeni. 2015. "Pengaruh Motivasi dan Persepsi Tentang Pembelajaran Mata Diklat Kompetensi Kejuruan APK Terhadap Hasil pembelajaran Siswa di SMK Negeri 1 Pamekasan". Jurnal Ekonomi Pendidikan dan Kewirausahaan, Vol.3 No.1: 35-47. 